\title{
THE SINKING OF SOVEREIGNTY AND SOVEREIGN RIGHTS? MITIGATING THE IMPACTS OF CLIMATE CHANGE TO MARITIME JURISDICTION AND A PROPOSAL FOR SOLUTIONS
}

\author{
I Made Andi Arsana ${ }^{1}$
}

\begin{abstract}
While some still debate whether or not climate change is a reality, one of its impacts, sea level rise, is factual. The cause and the rate of sea level rise might have been inconclusive but its impacts have been clearly felt. Sea level rise can also change the legal status of insular features (small islands/rocks and low tide elevation) that will also affect their capacity in making maritime claim. For an archipelagic State like Indonesia, small outer islands/rocks or low-tide elevation are important for location of basepoints forming the entire system of archipelagic baselines. This paper investigates the impact of sea level rise to the change of baselines and maritime limits a coastal state may claim. On the other hand, there is a need to have fixed maritime limits for better management and to balance rights and duties of coastal to the ocean. This paper provides options on how Indonesia as a coastal and archipelagic State can fix their baselines and or maritime limits in the face of coastal instability due to sea level rise as a consequence of climate change.
\end{abstract}

Keywords: baselines, climate change, sovereignty, jurisdiction, maritime limits, archipelagic state

\section{Introduction}

In early 2007, Indonesia's then Minister of Environment, Rachmat Witoelar, stated that around 2,000 islands of Indonesia were about to sink in 2030. ${ }^{2}$ Approaching the United Nations Framework Conference on Climate Change (UNFCCC) di Bali, he made a similar statement was even though without stating any specific number. ${ }^{3}$ Even though the statement was not adequately supported by primary data, Witoelar's statement certainly sparked debate in media up until mid 2008. Other parties such as Ministry of Marine Affairs and Fisheries, Agency for Meteorology and Geophysics also intensively discussed the issue of sinking islands following Witoelar's statement.

Climate change, like it or not, has become a highly debated issue in the

${ }^{1}$ Lecturer at the Department of Geodetic Engineering, Universitas Gadjah Mada. The author can be contacted at madeandi@ugm.ac.id.

2 ABS News, 2007. Indonesia May Lose 2,000 Islands to Warming: Minister Says Climate Change Could Lead To Rising Sea Levels, Accessed from < http://www.nbcnews.com/id/16867998/ns/world_ news-world_environment/\#.UhiUEj8vnDY>, on 15 August 2013.

3 Reuters 2007. Climate change may wipe some Indonesian islands off map, Accessed from <http://www.reuters.com/article/2007/12/03/environment-climate-indonesia-islands-dc-idUSJAK15507820071204> on 10 March 2011 
last decade or two with its critical impacts to the nature and the life of human being. One of the impacts is sea level rise, which brings particular challenges to coastal state in the world. The sea level rise can theoretically cause the submergence of low-land area, which eventually is harmful to habitat and human population living in the area. One of the impacts is the increase of vulnerability of coastal area due to storm surges resulting from an increasing incidence of extreme weather events. In result, such areas become less and less habitable. ${ }^{4}$

The aforementioned phenomenon brings serious problem since coastal areas are highly inhibited. An rough estimation indicates that more than 3 billion people of the world live in coasta areas with a distance of less than $200 \mathrm{~km}$ from coastline. ${ }^{5}$ In addition, people live not only close to the coast but also very close to sea surface. Consequently, an approximate sea level rise of 1 meter may sink land area inhibited by around 60 million people (Ananthaswamy, 2009: 30-31). Similarly, another analysis also reveals that around $60 \%$ of Indonesian population live in coastal area. ${ }^{6}$

For small islands countries like those in the Pacific, for example, sea level rise is a serious threat. It can significantly shift coastline landward so that the land shrinks. While a larger area may have enough space to anticipate this coastline shift, it is not the case with small islands. Not only does sea level rise may decrease the size of land, it can totally submerge them in the case of extreme sea level rise. Hypothesis on the sinking of Indonesian small islands seem to find its justification since climate change can indeed cause significant sea level rise.

The impact of sea level rise to the life of human being has become parts of many parties' serious concern. From the one perspective, this might be seen as a landward impact. Sea level rise also certainly has seaward impact, which concerns the size of maritime area a coastal state is entitled to pursuant to the international law of the sea. Sea level rise can change coastline, which means the change of baselines and eventualy cause the change ot maritime zone of jurisdiction a coastal State i entitled to. This paper discuss the impact of sea level rise as the consequence of climate change to the shif ot maritime zone of jurisdiction. It covers principles of costal States' entitlement of maritime areas and principle of maritime division between countries. Following that, impacts of sea level rise are discussed as the important part of the paper. Uneven impacts of sea level rise is also highlighted followed by response options to address the issue.

This paper is mainly a theoretical analysis, which apply generally regardliess of geographical context. This paper does not specifically discuss any particular case but provide adequate focus on Indonesia as an archipelagic State. Technical and legal terms such as baselines, basepoints, maritime jurisdictions, maritime boundareis are extensively used in this paper, the definition of which are provided subsection 4 of this paper and are illustrated relevant figures.

${ }^{4}$ Schofield, C. and Arsana, I M. A., Imaginary Islands? Options to Preserve Maritime Jurisdictional Entitlements and Provide Stable Maritime Limits in the Face of Coastal Instability, Ablos Conference, Monaco, 25-27 October 2010.

${ }^{5}$ Walker, G. and King, D. 2008. The Hot Topic: How to Tackle Global Warming and Still Keep the Lights On, London.

${ }^{6}$ Tarigan, M. S. 2007. Perubahan Garis Pantai Di Wilayah Pesisir Perairan Cisadane, Provinsi Banten, Makara, Sains, Vol. 11, No. 1, April 2007: 49-55 


\section{Climate Change: An Open Ending Debate}

Research and discussion on climate change has been intensively carried out by many parties. Even though views from different parties seem to converge in many aspects, this topic apparently remains a debate among scientists, national/international leaders and policy makers. ${ }^{7}$ Debates also take place between those who believe that climate change is a reality and those who believe that it is merely a myth. Some even believe that climate change is a lie that is intentionally disseminated for specific purposes. ${ }^{8}$ Having observed the trend of these debates, it seems unlikely that those different parties will reach one sigle agreement on how they view climate change. ${ }^{9}$

Debates also concern the cause and impacts of climate change. ${ }^{10} \mathrm{How}^{-}$ ever, several available scientific evidences confirm that climate change is a reality. For example, the change of season pattern (duration of summer, falls, winter and spring) in some sub-tropical regions can really be felt for the last couple of years. ${ }^{11}$ Similarly, the pattern of wet and dry season in tropical regions like Indonesia has also experience anomaly so that it affect farming and fisheries activities. ${ }^{12}$ In addition, one of the finding the Intergovernmental Panel on Climate Change (IPCC) leads to a conclusion that climate change is a reality which is unequivocally human-induced).$^{13}$ This IPPC's finding is one of the strong reasons of the UNFCCC in Bali at the end of 2007..$^{14}$

Sea level rise has been widely acknowledged as a reality. CSIRO of Australia, for example, asserts that the rate of sea level rise reaches $1.7 \mathrm{~mm}$ per year within the $20^{\text {th }}$ century with a rate of up to $3.4 \mathrm{~mm}$ per year during the period of 1993 to $2007 .{ }^{15}$ However, different sources reveal different data regarding the rate of sea level rise and debates remain in place

The principle causes of sea level rise arise from the thermal expansion of the oceans and the disintegration of land-based ice sheets. The first of these, the so-called 'steric effect', occurs as a consequence of the increasing atmospheric temperatures associated with global warming. As air temperatures rise so, gradually and incrementally, the oceans also warm. As they warm,

7 The Times Online 2009. EU's new figurehead believes climate change is a myth, The Times Online 2 January 2009. Diakses dari <http://www.timesonline.co.uk/tol/news/world/europe/article5430362. ece> tanggal 3 Maret 2011.

${ }^{8}$ Leiserowitz, A. A. 2005. American Risk Perceptions: Is Climate Change Dangerous?, Risk Analysis, Vol. 25, No. 6.

9 See above note 3

${ }^{10}$ Daily Mail 2007. Greenhouse effect is a myth, say scientists. Diakses dari <http://www.dailymail. co.uk/sciencetech/article-440049/Greenhouse-effect-myth-say-scientists.html> tanggal 15 Maret 2011

11 Duzheng, Y. Yundi, J. and Wenjie, D. 2003. The northward shift of climatic belts in China during the last 50 years and the corresponding seasonal responses, Advances in Atmospheric Sciences, Volume 20, Number 6, pp. 959-967.

12 Presiden RI 2011. Presiden Hadiri Pencanangan Gerakan Nasional Menghadapi Anomali Iklim. Diakses dari < http://www.presidenri.go.id/index.php/fokus/2011/01/14/6347.html> tanggal 5 Maret 2011.

13 IPCC 2007. IPCC's Fourth Assessment Report (AR4). Diakses dari <http://www.ipcc.ch/\#> tanggal 12 Maret 2011.

${ }^{14}$ Personal communication with Rachmat Witoelar (Head of the Indonesian Delegation in COP15, Copenhagen) in December 2009 in Sydney.

15 CSIRO 2009. The science of climate change, CSIRO. Diakses dari <http://www.csiro.au/files/ files/poqu.pdf> tanggal 12 March 2011. 
surface waters expand and this in turn translates to a rise in sea level. Considerable uncertainty surrounds the whether and how swiftly land-based ice sheets such as those of Antarctica and Greenland, are melting. Consequently, the IPCC did not factor in this potential loss leading to its relatively moderate predictions in its Fourth Assessment Report of 2007 estimating the range of sea-level rise at between 0.38 to 0.59 metres above 1990 levels by 2100, with a mid-range prediction of the order of 40 centimetres. ${ }^{16}$

IPCC's conservative approach highlighted above also attract has been critisised. Meanwhile, some other analysis state that if the melting of ice in the polar region is considered, it is likely that the rate of sea level rise is predicted higher. For example, there is strong indication that the melting of ice in Greenland may cause sea level rise of around six to seven meter. ${ }^{17}$ Even though this is based on the assumption that the entire iece in Greenland has melted, it is clear that the rate of sea level rise is potentially higher that that predicted by IPCC. This seems to te the reason why coastal States are preparing themselves to face muc higher sea level rise that that predicted by IPCC). ${ }^{18}$ Department of Climate Change of Australia, for example, published their study "Climate Change Risks to Australia's Coast: A First Pass National Assessment" in November 2009. The report ellaborates the worst case scenario of sea level rise of 1.1 meter in $2100 .{ }^{19}$ Meanwhile, as previously mentioned, issue on climate change in Indonesia is even more worrying. It is stated that around 2000 islands in Indonesia will disappear in 2030 due to sea level rise. Following Rachmat Witoelar's statement about the issue in 2007, Prof. Indroyono Susilo of the Ministry of Marine Affairs and Fhishereis reiterated the statement in February 2008. ${ }^{20}$

It is worth noting that sea level rise is also influenced by a long-term cycle and other natural process. In addition, there are differences between climate variability and climate change, both of which are often misuderstood. Climate variability is short term in nature (daily, seasonal, annually, etc), which include fluctuation in relation to the occurence of El Niño (dry) or La Niña (wet). Meanwhile, climate change is the average trend of climate in a long-term (decate or more), which has been observed in centuries. It also involves long-term change regarding variability such as requency, how bad the impacts is, and uration of extreme phenomena. ${ }^{21}$ In other words, not all of the variation of climate can be considered as part of climate change.

Apart from sea level rise, it has been evident that land subsidence also contributes to the submergence of certain coastal areas. It has been con-

\footnotetext{
${ }^{16}$ See, the IPCC's Fourth Assessment Report (AR4), available on the internet at, <http://www.ipcc. ch/\#> (last accessed 21 November 2009).

17 (Walker and King, 2008: 778-780 in Schofield, C. and Arsana, I M. A., Imaginary Islands? Options to Preserve Maritime Jurisdictional Entitlements and Provide Stable Maritime Limits in the Face of Coastal Instability, Ablos Conference, Monaco, 25-27 October 2010. See above note 3 and 4

18 . See above note 3

19 Department of Climate Change 2009. Climate Change Risks to Australia's Coast: A First Pass National Assessment available at <http://www.climatechange.gov.au/en/publications/coastline/climatechange-risks-to-australias-coasts.aspx>.

${ }^{20}$ Antara 2008 2000. Pulau Akan Tenggelam pada 2030. Diakses dari <http://www.antaranews. com/view/?i=1204115346\&c=WBM\&s=> tanggal 10 Maret 2011

${ }^{21}$ Climate Kelpie 2010. Climate variability and climate change - what's the difference? Diakses dari <http://www.climatekelpie.com.au/understand-climate/climate-change-science/climate-variability-andclimate-change-whats-the-difference> tanggal 10 Maret 2011.
} 
firmed, for example, that land subsidence is responsible to the submergence of part of Semarang City, Central Java. ${ }^{22}$ It reveals that the dynamic position of sea level relative to the land is not only caused by sea level rise but also land subsidence. It does not matter whether it is sea level rise of land subsidence, this has been confirmed to be a reality and certainly causes serious impacts to most (if not all) of the world's population. ${ }^{23}$ In line with that, there are indications that global sea level rise does happen. Sea level rise, whether it is absolute or relative, causes the change of coastlines, especially low water used as baselines, that may eventually affect maritime zone of jurisdiction that such coastal States can claim or are entitled to.

\section{Maritime Claims and Delimitation}

\section{A. Baselines in the context of the law of the Sea}

Pursuant to the United Nations Convention on the Law of the Sea 1982 (hereinafter referred to as Law of the Sea Convention, LOSC) ${ }^{24}$ a coastal State is entitled to zones of maritime jurisdiction measured from its baselines (see subsection B). In accordance to LOSC, coastal States can opt to designate 'normal' baselines ${ }^{25}$ or straight baselines. ${ }^{26} \mathrm{~A}$ state that qualifies as an archipelagic State according to $\operatorname{LOSC}^{27}$ can designate archipelagic baselines "joining the outermost points of the outermost islands and drying reefs of the archipelago."28 In additions to those, baselines can also include lines closing mouth of rivers ${ }^{29}$ and mouth of bays ${ }^{30}$ and baselines related to ports ${ }^{31}$ and roadsteads ${ }^{32} \mathrm{~A}$ state may use a combination of different types of baseline to construct the overall baseline around its coastline. ${ }^{33}$

Irrespective of the types, baselines are vital in defining the outer limits of maritime zones a coastal State is entitled to. Landward of a coastal State's baselines lie either its land territory, including the inter-tidal foreshore landward of normal low-water line baselines, or internal waters. Baselines serve as the starting point from where the outer limits of maritime zones (see subsection 3.2) are measured. In addition, baselines are also important in constructing equidistance lines between coastal States in the delimitation of maritime boundaries. In this context it is notable that equidistance lines, the

22 Sutanta, H., Rajabifard, A. and Bishop, I. D. 2009. "An Integrated Approach for Disaster Risk Reduction Using Spatial Planning and SDI Platform”, pp.341-351 in Ostendorf B., Baldock, P., Bruce, D., Burdett, M. and P. Corcoran (eds). Proceedings of the Surveying \& Spatial Sciences Institute Biennial International Conference, Adelaide 2009, Surveying \& Spatial Sciences Institute.

${ }^{23}$ See above note 3

24 United Nations Conventions on the Law of the Sea (LOSC), opened for signature 10 December 1982, in force 16 November 1994, 1833 UNTS 3.

$\begin{array}{ll}25 & \text { LOSC Article } 5 . \\ 26 & \text { LOSC Article } 7 . \\ 27 & \text { LOSC Article } 46 . \\ 28 & \text { LOSC Article } 47 . \\ 29 & \text { LOSC Article } 9 . \\ 30 & \text { LOSC Article 10. } \\ 31 & \text { LOSC Article } 11 . \\ 32 & \text { LOSC Article } 12 . \\ 33 & \text { LOSC Article } 14 .\end{array}$


construction of which necessarily depend on the use of baselines, have proved to be by far the most popular method of delimitation. ${ }^{34}$

Of particular note in the context of sea level rise, the normal baselines of a coastal State are the "low-water line along the coast as marked on large scale charts officially recognized by the coastal State." ${ }^{35}$ In their designation, normal baselines do not require coastal States to make active claim or publication. In addition, if a State does not publish any type of baselines, then it employs normal baselines since they are "a coastal state's default baselines." ${ }^{36}$ This is the predominant type of baseline worldwide. Article 5 of LOSC does not specify a particular low water line that should be used, this choice is left to the coastal state. The particular low water line opted for is, in turn, dependent upon the choice of the vertical level (technically the 'vertical datum') that represents 'zero' from which heights and depths are measured. This reference level intersects the coast as the low water line.

The rule of thumb is that the higher the vertical datum is, the closer landward the location of baselines will be. Similarly, the lower the vertical datum then the further 'down the beach' the low water line, and thus the starting line for the measurement of maritime claims, generally becomes. Unsurprisingly, States have tended to favour the application of low vertical datums in order to determine their low water lines and thus normal baselines. In practice, many coastal States favour the use of lowest astronomical tide (LAT) for this purpose. LAT is a particularly low vertical datum, and thus low water line, consisting of "the lowest level which can be predicted to occur under average meteorological conditions and under a combination of astronomical conditions." ${ }^{37}$ LAT is based on observations made over a period of 18.6 years, "identified as the relative rotation of the lunar and solar orbits or regression of the lunar nodes." 38

Unlike normal baselines that do not require declaration, other types of baselines such as straight, mouth of river closing lines, and bay closing lines need to be explicitly declared. The baselines "shall be shown on charts of a scale or scales adequate for ascertaining their position" or alternatively they can also be presented in "a list of geographical coordinates of points, specifying the geodetic datum". ${ }^{39}$ Coastal states need to give due publicity to the charts or list of coordinates need and provide their copy to the Secretary-General of the United Nations. ${ }^{40}$ This is also applicable to archipelagic baselines an ar-

34 See, for example, Prescott, J.R.V. and Schofield, C.H. (2005) The Maritime Political Boundaries of the World (Leiden/Boston: Martinus Nijhoff Publishers), at pp.239-241.

35 LOSC Article 5

36 Beckman, R., and Schofield, C. (2009) “Moving Beyond Disputes Over Island Sovereignty: ICJ Decision Sets Stage for Maritime Boundary Delimitation in the Singapore Strait", Ocean Development and International Law, Vol. 40:1: 1-35, at p. 5.

37 See International Hydrographic Organization (IHO) (with the International Oceanographic Commission and the International Association of Geodesy), A Manual on Technical Aspects of the United Nations Convention on the Law of the Sea, 1982, Special Publication No 51, 4th edition, International Hydrographic Bureau, Monaco 2006, ch 2, 18. This publication is often referred to as the 'TALOS Manual'.

38 Sobey, R. J., (2005). Extreme low and high water levels, Coastal Engineering, Vol. 52, p. 65.

39 LOSC Article 16 (1). Geodetic datum is a reference from which measurements are made. In surveying and geodesy, a datum is a set of reference points on the Earth's surface against which position measurements are made. Without specific geodetic datum, coordinates are meaningless, the actual location of which cannot be define on earth.

$40 \quad$ LOSC Article 16 (2) 
chipelagic State can designate pursuant to the LOSC. ${ }^{41}$ With regard to the use of vertical datum, baselines other than normal baselines are also dependent upon the choice of vertical datum. Turning points of straight and archipelagic baselines, for example, need to be anchored to the coast as represented by the low water line. In short, the position of low water line will eventually affect the designation of baselines, irrespective of their types.

\section{B. Zones of Maritime Jurisdictions}

Measured seaward from its baselines, a coastal State may theoretically claim the full suite of zones of maritime jurisdiction provided for in accordance with LOSC. These zones include a 12 nautical miles (M) breadth territorial sea, a contiguous zone out to $24 \mathrm{M}$ from baselines (or $12 \mathrm{M}$ from territorial sea limits), an exclusive economic zone (EEZ) out to $200 \mathrm{M}$ and continental shelf that may extend up to $350 \mathrm{M}$ or even more (see Figure 1). ${ }^{42}$ The outer limits of continental shelf, unlike the limits of other zones which depend only on distance, depend also on geology and geomorphology of seabed. That is why the outer limit of continental shelf is not as fixed as other zones'. In addition to the aforementioned zones, a coastal State is also entitled to, when applicable, internal waters measured landward from baselines.

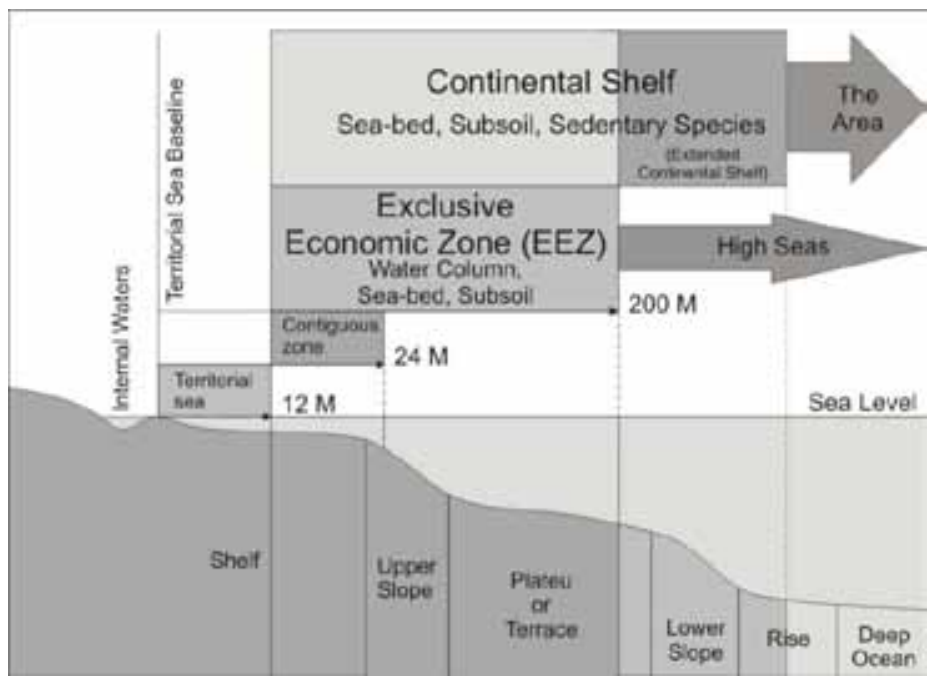

Figure 1 Maritime jurisdictions of a coastal State according to the LOCS

For each maritime zone, a coastal States exercise either full sovereignty or only sovereign rights for specific purposes. Coastal States have sovereignty over internal waters, over archipelagic waters within archipelagic baselines such as those defined by coastal States) and over the territorial sea. With regard to all of these zones the coastal State's sovereignty extends through the seabed and subsoil, water column and airspace above. Within the Exclusive

${ }^{41}$ LOSC Article 47 (8) (9)

${ }^{42}$ LOSC Article 3, 33, 57 and 76 respectively. 
Economic Zone and continental shelf, by contrast, coastal States have specific sovereign rights to utilise and manage natural resources (fishing, oil and gas mining, etc). While the Exclusive Economic Zone relates to both seabed and subsoil and the water column overlying the seabed, the continental shelf relates solely to the seabed and subsoil..$^{43}$ The High Seas are part of the sea which excluding the EEZ, the territorial sea or the internal waters of a coastal State, or the archipelagic waters of an archipelagic State. ${ }^{44}$ Meanwhile, The Area covers seabed region beyond coastal States' continental shelf, which is considered as the common heritage of mankind. ${ }^{45}$

A further difference between the various maritime zones of jurisdiction is that fact that some of them, such as the Exclusive Economic Zone, require an active claim on the part of the coastal State and some do not. In particular, continental shelf rights are inherent and "do not depend on occupation, effective or notional, or on any express proclamation". ${ }^{46}$ This means that a coastal State may explore and exploit natural resources within its continental shelf without making an express claim to it. The basis for this distinct treatment rests on the concept that the coastal State possesses rights to its continental shelf as the "natural prolongation of its land territory" into and under the sea ${ }^{47}$ LOSC provides that a coastal State's continental shelf extends beyond the limits of its territorial sea "to the outer edge of the continental margin" or, to $200 \mathrm{M}$ from its relevant baselines where the continental margin does not extend to that distance. The procedure to delineate the outer limits of continental shelf beyond $200 \mathrm{M}$ is set out in Article 76 of the LOSC (see below).

\section{Setting the Limits of Maritime Jurisdiction}

The limits of a coastal State's maritime jurisdiction can be established in one of three ways. First, maritime claims can be generated to the full extent allowed for under international law, in the absence of analogous claims on the part of neighbouring States. Second, where overlapping claims to maritime jurisdiction exist, maritime boundaries may be delimited between neighbouring States. Thirdly, with respect to continental shelf limits, the definition of its outer limits involves a submission process to the United Nations Commission on the Limits of the continental shelf as previously mentioned (see also below).

Provided that a coastal State does not have any neighbours having overlapping claim for a particular zone, such coastal state can define its maritime limits unilaterally. For example, if the coastal State has no neighbours within $24 \mathrm{M}$ distance from its baselines, it can unilaterally define its territorial sea limits. With regard to this option, the outer limits of maritime zones are commonly defined using the method of envelope of arc. ${ }^{48}$ The limits of such claims

43 It is worth noting, however, that rights over seabed and subsoil claimed as part of the EEZ under Part V of LOSC are exercised in accordance with LOSC Part VI dealing with the continental shelf. See, LOSC, Article 56(3).

44 LOSC, Article 86.

45 LOSC, Article 136

46 LOSC, Article 77(3).

47 LOSC, Article 76(1).

48 Carleton, C.M. and Schofield, C.H. (2001) Developments in the Technical Determination of 
are generally dependent on the baselines from which these maritime claims are measured and thus may move over time as such baselines shift. However, it is worth noting that the use of this method employs only relevant basepoints along baselines to generate maritime limits. Depending on the shape and configuration of baselines, not every point along baselines will have effects to location of maritime limits. In other words, while some part of baselines may be crucial in constructing maritime limits, other part of the baselines may not contribute as much due to its geographical location along the baselines. However, it is generally true that the changes of baselines can shift maritime limits.

It has been observed that if all coastal States were to make their maximum maritime claims permitted by the LOSC, around $44.5 \%$ of the world ocean could possibly fall under some form of national jurisdiction. This means that the remaining high seas would encompass approximately 55.5\% of world's ocean surface. ${ }^{49}$ Interestingly, it is hard to find that a coastal State can claim a full suit of maritime zones without having overlapping claims with its neighbours. To be able to fully claim EEZ, for example, distance of a coastal State from its neighbours must be more than 2 times $200 \mathrm{M}$. For the case of continental shelf, the distance required may be even more. ${ }^{50}$ However, this situation does not impact the way the breadth of maritime zones are, theoretically, measured from baseliConsidering the geographical location of coastal States in the world and the configuration of their coasts, overlapping claims of maritime zones among coastal States is inevitable (see Figure 2). Consequently, maritime delimitation is required to produce maritime boundaries. Maritime delimitation between States is therefore another way for coastal States to define the limits of their maritime zones. While the first option is a unilateral process, maritime delimitation in the second option is a bilateral or multilateral process.

Maritime Space: Charts, Datums, Baselines, Maritime Zones and Limits, Maritime Briefing, 3, 3, Durham: International Boundaries Research Unit, at p.62.

49 Pruett, L. 2004. Area Calculations of the Claims and Potential Claims to Offshore Jurisdictional Zones and High Seas, unpublished data derived from the August 2003 Edition of the Global Maritime Boundaries Database, General Dynamics, Herndon, VA, USA, in Prescott, V. and Schofield, C. 2005. The Maritime Political Boundaries of the World, 2nd edition, Martinus Nijhoff Publishers, p. 9, 27

50 Pursuant to Article 76 of LOSC, continental shelf can extend up to a distance of $350 \mathrm{M}$ or even more. 


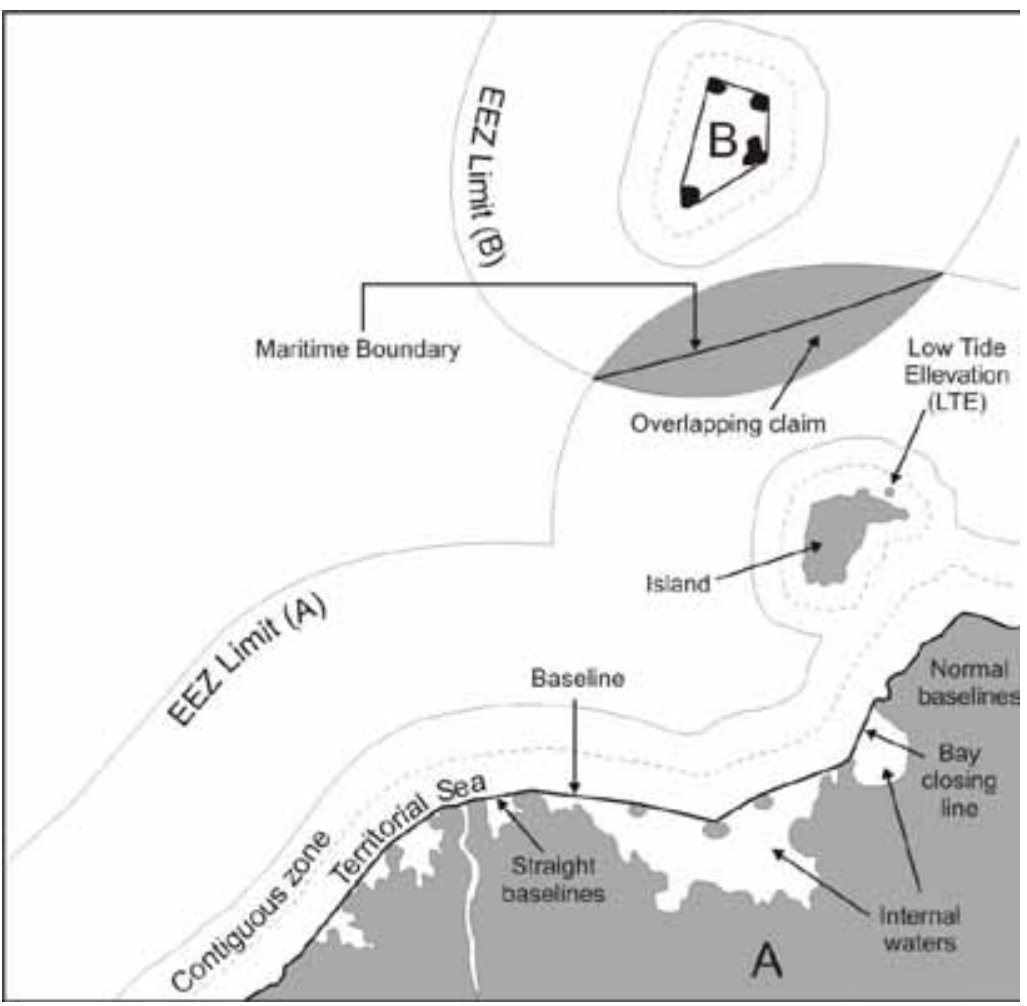

Figure 2 Maritime zones based on LOSC

The process of maritime boundary delimitation between two or more coastal states is governed by the principles and rules of public international law. ${ }^{51}$ International law provides the "rules of the game" explaining how maritime boundary delimitations should be established. However, maritime boundary delimitation is usually resolved either through negotiation among affected parties or by submission of the case to the third party. ${ }^{52}$ This third party can be arbitrators, mediators, courts or tribunal such as the International Court of Justice (ICJ) ${ }^{53}$ and the International Tribunal for the Law of the Sea (ITLOS). ${ }^{54}$

Figure 2 shows that overlapping claim takes place in EEZ and continental shelf because distance between State A and B is less then $400 \mathrm{M}$ but is more than $24 \mathrm{M}$. should the distance between those two neighbouring States is less than $24 \mathrm{M}$ then their territorial sea will overlap one another. This is to illustrate that maritime boundary delimitation can be required for territorial sea, EEZ, or continental shelf, depending on the distance between States in question. In this regard, rules governing maritime boundary delimitation

51 Prescott, JRV. and Schofield, C., (2005). The Maritime Political Boundaries of the World, Second Edition, Martinus Nijhoff Publishers, Leiden/Boston, 218

52 Ibid

53 See: International Court of Justice at <http://www.icj-cij.org>

54 See: International Tribunal for the Law of the Sea at <http://www.itlos.org> 
for those different zones are also different. For territorial sea for example, it is explicitly stated by the LOSC that "neither of the two opposite or adjacent states is entitled to extend its territorial sea beyond the median line" unless either state involved agrees otherwise, or due to the existence of "historic title or other special circumstances"..$^{55}$ It is understood from this provision the method to delimit territorial sea is explicitly mentioned in the LOSC, which is median line or equidistance line. ${ }^{56}$ However, the LOSC does not specifically mention methods in delimitating EEZ and continental shelf boundaries in case overlapping claims between two or more state are identified. Provisions in the LOSC only mention that EEZ boundaries between States with opposite or adjacent coast should be established to "achieve an equitable solution." ${ }^{57}$ "Equitable solution" is also the term used for the delimitation of continental shelf in the case of overlapping claims between States. ${ }^{58}$ Notwithstanding the positive intention of LOSC in using the term "equitable solution" in delimiting EEZ and continental shelf boundaries, the Convention does not specifically mention the method to be used in establishing boundary lines.

One important aspect about maritime boundaries settled bilaterally/ multilaterally is that they stay where they are. Maritime boundaries do not change unless parties in question agree to do so. The 1969 Vienna Convention on the Law of Treaties states that boundary treaties are excluded from the rule that a party to a treaty may invoke "a fundamental change in circumstances" as a ground for terminating a treaty. ${ }^{59}$ In addition, the 1978 Vienna Convention on Succession of States in Respect of Treaties also provides that a change of states does not affect a boundary established by a treaty ${ }^{60}$ In other words, agreed maritime boundaries are fixed in term of location even if baselines from which they are constructed have shifted.

The third option to define the outer limits of maritime jurisdiction is through a submission to a third party as in the case of continental shelf beyond $200 \mathrm{M}$ from baselines. In order to confirm its sovereign rights over areas of continental shelf beyond 200 nautical miles from its baseline, LOSC provides that a coastal State should make a submission regarding its proposed outer continental shelf limits, mainly on the basis of geological and geomorphologic evidence, and submit this to the United Nations Commission on the Limits of the Continental Shelf (CLCS or the Commission). ${ }^{61}$ The continental shelf beyond 200 nautical miles from baseline is commonly termed the 'outer' or 'extended' continental shelf or ECS (see Figure 1), the outer limit of which involve complicated procedures and enormous of resources. The procedure for the delineation of the outer limits of continental shelf beyond $200 \mathrm{M}$ was also detailed by the Commission in its Scientific and Technical Guidelines

$55 \quad$ LOSC, Article 15

56 The Manual on the Technical Aspects of the LOSC published by International Hydrographic Bureau (2006: 6-3) states that the term "median line" is similar to "equidistance line", "a line every point of which is equidistant from the nearest points on the territorial sea baselines of two States."

57 LOSC, Article 74

58 LOSC, Article 83

59 Vienna Convention 1969, Article 62 (2)(a)

60 Vienna Convention 1978, Article 11 (a)

61 The Commission on the Limits of the Continental Shelf was established pursuant to LOSC, Annex II. It consists of 21 members of experts in Geology, Geophysics, Hydrography, and Geodesy, who are elected from state parties to the LOCS every five years. More information of the Commission can be obtained from its official website: http://www.un.org/Depts/los/clcs_new/clcs_home.htm. 
(CLCS/11) which were adopted on May 13, 1999.62 Once the Commission has delivered its recommendations to the coastal State, that State may declare the outer limits of its outer continental shelf which are "final and binding" when defined "on the basis of" the Commission's recommendations. ${ }^{63}$ In other words, even though the outer limit of continental shelf is not definitive in term of distance from baselines, unlike the outer limits other zones, the limit is fixed in term or location, once it has been properly established.

From the three options to set the limits of maritime jurisdictions elaborated above, the first generates unfixed maritime limits while the last two established fixed one. Shifting maritime limits in the first option is due to shifting baselines, especially the normal one. The changing of coastal environment will eventually change coastlines which in turn can change the configuration of normal baselines. This consequently will change the outer limits of maritime limits. Meanwhile, agreed maritime boundaries and outer limits of continental shelf beyond $200 \mathrm{M}$ are fixed.

\section{Potential Impacts of Climate Change}

\section{A. Ambulatory baselines and shifting maritime limits}

It has long been recognised that parts of the coast are dynamic and can change location and configuration in relatively short periods of time or "ambulate". ${ }^{64}$ Indeed, coastlines often change in a cyclical manner over time (alternately shifting seawards through deposition or accretion of material and then landwards as a consequence of erosion). ${ }^{65}$ The location of normal baselines will therefore tend to move over time. The traditionally generally accepted implication of this phenomenon is that as normal baselines change, so too will the maritime jurisdictional limits measured from them. Thus, where the baseline advances (for example, by the deposition of material along the coast) the outer limits of the maritime claims measured from that baseline will likewise expand seawards. Conversely, where the normal baseline recedes (through coastal erosion), the coastal state may 'lose' maritime areas as their maritime limits are likewise pulled back.

Since normal baselines are represented by low-water line, sea level is an important issue in the definition of normal baselines. That said, whilst normal, low water line, baselines would seem to be most obviously susceptible to change as a consequence of sea level rise, other types of straight line type baseline are also potentially threatened by sea level rise as such baselines

62 The Scientific and Technical Guidelines of the Commission contains technical and scientific procedure to define the outer limits of continental shelf. It is published in document CLCS/11 and is available online at <http://www.un.org/Depts/los/clcs_new/commission_documents.htm\#Guidelines>. For other analysis concerning outer continental shelf delineation, see for example: Schofield, C. Arsana, I M. A. and van de Poll, R. (2010), 'The Outer Continental Shelf in the Asia-Pacific Region: Progress and Prospects' in Vidas, D (ed) Law, Technology and Science for Oceans in Globalization, Martinus Nijhoff.

63 LOSC, Article 76 (8).

64 Reed, M. Shore and sea boundaries: the development of international maritime boundary principles through United States practice, (Washington D.C.: US Department of Commerce, 2000), at 185; Prescott and Schofield, Maritime Political boundaries of the World, supra note 22, at 100-101.

65 See, for example, Hirst, W. and Robertson, D., "Geographic Information Systems, Charts and UNCLOS - Can They Live Together?", Maritime Studies, 136 (May-June 2004), at 1-6. 
need to be anchored to the coast as represented by the low water line.

Rising sea levels will generally tend to lead to the retreat inland of the low water line, and thus the normal baseline. This can result in significant 'knock on' impacts on the limits of maritime jurisdictional claims if the basepoints, on which the limits of such claims depend, similarly retreat inland. This threat to the extent of national maritime jurisdictional claims is especially significant for coastal states such as Bangladesh which have large stretches of low lying coasts. The maritime claims of States in possession (or, indeed, entirely composed) of low elevation islands, are also under threat from this phenomenon. Small, remote and low lying islands can give rise to significant maritime jurisdictional entitlements. However, sea level rise could change the legal status of such insular features (see Figure 3). For example, an island presently always above water surface even during high tide may, as a consequence of sea level rise, eventually disappear during high tide. This could lead to it being reclassified from an island from which claims to the full range of maritime zones may be made, to one of the categories of insular formation from which only restricted maritime claims can be made such as a 'rock' or a low tide elevation (features that are exposed at low tide but are submerged at high tide) or even a fully submerged feature which cannot be used to generate maritime claims. ${ }^{66}$

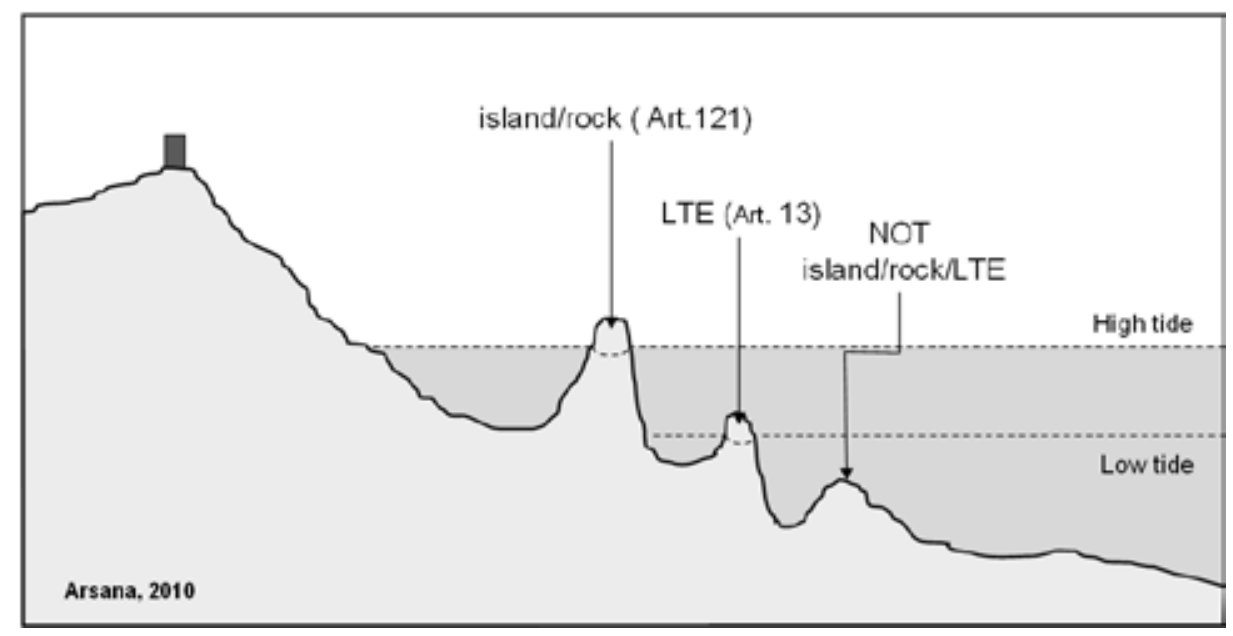

Figure 3 Insular features and sea tides

\section{B. Uneven impacts}

While, as noted above, sea level rise would logically and inevitably seems to result in the retreat of normal baselines inland, it is important to recognise coastal complexity and variability. Accordingly, sea level rise is likely to result in uneven consequences in terms of impacts on maritime jurisdictional claims.

For example, the gradient of the coast is an important factor. Where the

${ }_{66}$ Schofield, C.H. 'Shifting Limits?: Sea Level Rise and Options to Secure Maritime Jurisdictional Claims'(2009) 4 Carbon and Climate Law Review, pp.405-16, at pp.409-410. 
coastline is relatively steep in gradient, the impact of sea level rise will be limited in terms of shifting the location of baselines (and thus the maritime jurisdictional limits derived from them) horizontally. Conversely, where the coastline is gently shelving, even relatively slight changes in sea level vertically can result in significant shifts in the location of the low water line horizontally and this, in turn, can have significant impacts on the spatial extent of national maritime claims.

Figure 4 illustrates two different sea levels and two distinct coastline gradients. The impact of a rise in sea level from Level 1 to Level 2 is significantly more pronounced in terms of the horizontal change or recession inland in the location of the normal baseline for the shallower gradient coastline shown. In short, the steeper the coastal area is, the less the impact will be. A very shallow foreshore gradient, for example $5 \%$ or less (around $3^{\circ}$ measured from horizontal line), will be affected by around 20 meters of horizontal distance on the location of the normal baseline as a result of one meter difference in vertical datum. For the same difference in vertical datum, a steep foreshore gradient, for example $173 \%$ or more (around $60^{\circ}$ measured from horizontal line), can be affected only by 0.5 meters of horizontal distance. In this context it is worth noting that errors in the definition of the vertical datum can also affect the location of baselines, which depends on the gradient of foreshore. ${ }^{67}$

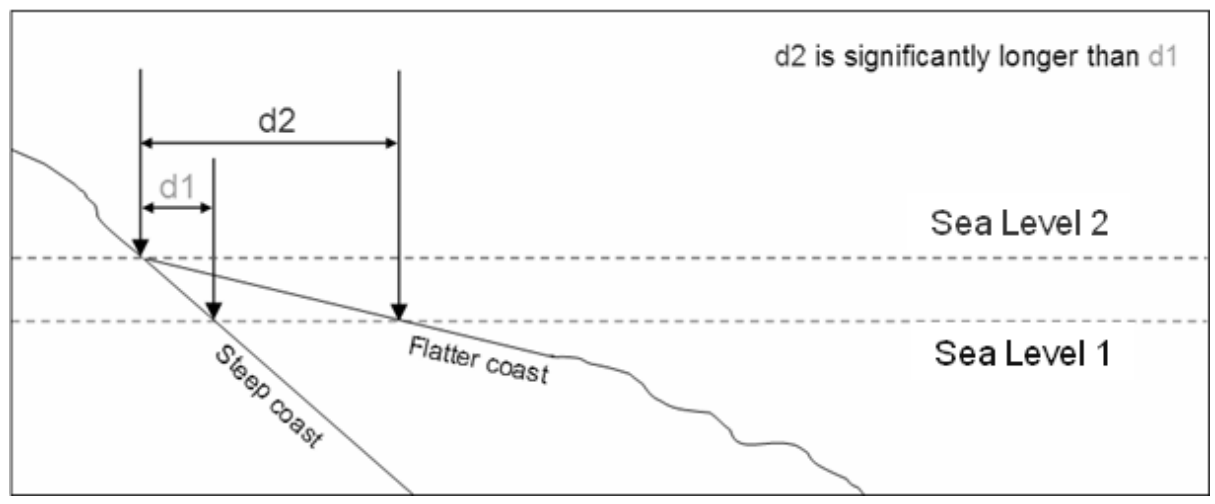

Figure 4 The impact of different sea levels on different gradients of coast

It is also the case that not all of a coastal State's baselines contribute towards the construction of the outer limits of its maritime claims. Maritime limits are commonly constructed through the 'envelope of arcs' method. ${ }^{68}$ Consequently, only certain basepoints along the normal baseline, essentially the outermost points along the baseline such as headlands and offshore islands, will be relevant to the limits of the maritime zones with the length of the arcs from the contributing basepoints being determined by the breadth of

67 Leahy, F.J., Murphy, B. A., Collier, P. A., and Mitchell, D. J., (2001). Uncertainty Issues in the Geodetic Delimitation of Maritime Boundaries, Proceeding of the 2001 ABLOS Conference. Available at <http:// www.gmat.unsw.edu.au/ablos/ABLOS01Folder/LEAHY.PDF> (last accessed 29 August 2010).

68 Carleton, C.M. and Schofield, C.H. (2001) Developments in the Technical Determination of Maritime Space: Charts, Datums, Baselines, Maritime Zones and Limits, Maritime Briefing, 3, 3, Durham: International Boundaries Research Unit, at p.62. 
the maritime zone for which the outer limit is being constructed. In contrast, those parts of the baseline that are, for example, located on the inner portion of a bay, are unlikely to contribute to the outer limit of maritime zones. Indeed, the majority of the baseline is irrelevant to the construction of the outer limits to maritime jurisdictional zones.

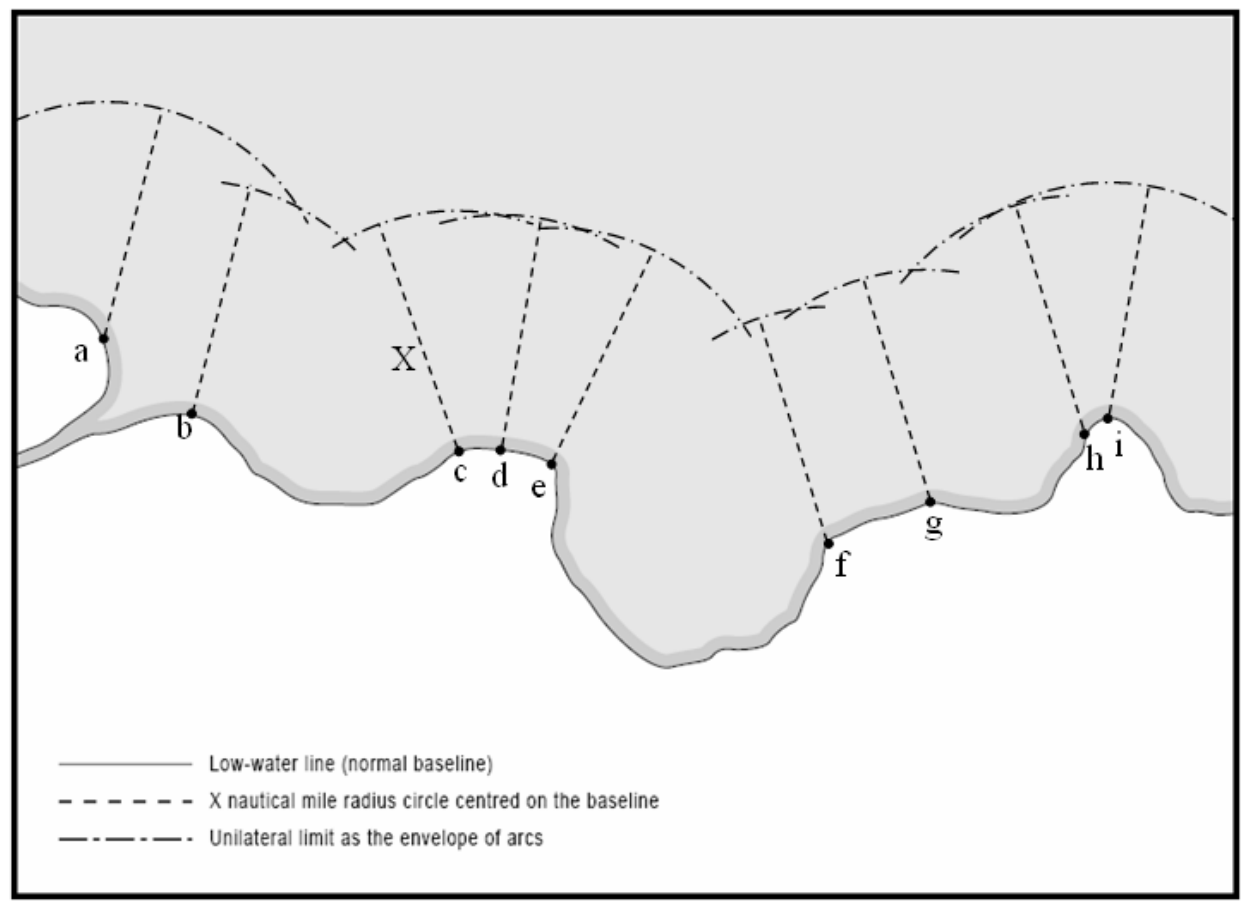

Figure 5 Envelope of arc and relevant basepoints

Figure 5 illustrates that, only points a, b, c, d, e, f, g, h, and i contribute to the construction of the envelope of arc which define the maritime limits. Any point along the baseline between e and f, for example, contribute nothing to the definition of maritime limits. Accordingly, should for some reason the e-f segment shifts landward, maritime limits will not be affected.

\section{Islands and coast under threat}

While large populations occupying low-lying coastal areas on continental coasts are arguably most at risk from sea level rise, it is noticeable that the debate on the issue tends to be framed, even dominated, by the concerns of and about a number of small island States. This focus, especially in the media narrative, perhaps stems from a perception that, in contrast to small low-lying island States, continental States have other, higher, land for displaced populations to retreat to. Additionally, the small island States are well placed to readily (and arguably rightly) elicit sympathy for their apparent predicament, especially as the small island states can argue convincingly that they have done perhaps the least to cause global climate change through the emission 
of greenhouse gases.

Concerns over sea level rise by and on behalf of these States have been in large part prompted by recognition that certain States not only possess limited land territory but, more particularly, little territory elevated above present sea levels. For example, the highest point on the territory of the Maldives his only 2.4 metres above sea level. Similarly, it has been suggested that sea level rise is already a real emergency for Tuvalu, ${ }^{69}$ which has accordingly been described as the "front line of climate change." ${ }^{70}$ Analogous concerns exist for other small, relatively low lying, island States.

While it has been suggested that sea level rise could ultimately lead to certain low-lying island States sinking beneath the waves and thus losing their status as States, ${ }^{71}$ this does not appear to be on the horizon at least in the near term. For example, even if sea levels were to rise by one metre, no State would be completely inundated. That said, even relatively slight sea level rises may have major impacts on island habitability. These concerns have led to the formation of bodies such as the Alliance of Small Islands States (AoSIS) has been established to address issues of their vulnerability to climate change. ${ }^{72}$

While there has been mounting evidence that impacts of sea level rise is generally negative, some may see it as an accidental benefit with regard in resolving sovereignty disputes. For instance, the alleged disappearance of a disputed island called South Talpatty (by Bangladesh) or New Moore (by India) was suggested as an unlooked for 'benefit' of climate change. However, in fact this did not prove to be the case as, not only were reports of the island's demise somewhat premature as it was reported that the island still appears during "very, very low tide conditions", 73 but (at least) one of the parties to the dispute, Bangladesh, promptly reasserted its sovereignty claim to the feature. It remains to be seen whether or not sea level rise will yet have a positive impact on long-standing, contentious island sovereignty disputes such as that over the Spratly Islands in the South China Sea or will merely add a further layer of confusion and uncertainty to already uncertain scenario. ${ }^{74}$

Notwithstanding mounting evidence suggesting threats to islands and coasts due to climate change, counterarguments do exist. For example, there is evidence to suggest that coral atolls have proven to be remarkably robust features over long time periods, including periods when sea levels were considerably higher than they presently are. This suggests that some insular fea-

69 A point noted by HE Mr. Enele Sosene Sopoaga, former Ambassador and Permanent Representative of the Mission of Tuvalu to the United Nations at the 2007 United Nations Framework Conference on Climate Change. See, Leake, J. (2007). Global warming and the world's low-lying countries, The Sunday Times. Available at <http://www.timesonline.co.uk/tol/news/environment/article3054040.ece> (last accessed 30 August 2010).

70 Patel, S. S. (2006) A Sinking Feeling, Nature Vol. 44, 6 April 2006, p. 734.

71 Article 1 of the Montevideo Convention on the Rights and Duties of States provides that a State should possess a "defined territory" and a "permanent population", as well as a government and the capacity to enter into international relations with other States. The first two of these four requirements could be directly impacted by sea level rise. See, Montevideo Convention on the Rights and Duties of States, opened for signature 26 December 1933, 165 LNTS 19 (entered into force 26 December 1934), Article 1.

72 See, Alliance of Small Islands States at <http://www.sidsnet.org/> (last accessed 1 September 2010).

73 Wade, M. (2009) Rising sea level settles border dispute, The Sydney Morning Herald. Available at <http://www.smh.com.au/environment/climate-change/rising-sea-level-settles-border-dispute20100324-qwum.html> (last access on 28 August 2010).

74 Dupont, A. (2008) The Strategic Implications of Climate Change, Survival, Volume 50: 3, p.36. 
tures may be able to naturally adapt to climate change and sea level rise. It could also been argued that overpopulation of small islands, coupled with inappropriate land uses are important factors impacting on the integrity of, for instance, coral island ecosystems and thus the continued habitability of such features.

\section{Responding to the impacts of Climate Change}

Either for sea level rise or land subsidence, it is evident that the current normal baselines are ambulatory in character, which in turn can shift maritime limits measured from them. On the other hands, there is a need to have fixed maritime limits for better ocean space management. Two options are possible to overcome this issue: stabilising the baselines and/or fixing the outer maritime limits.

\section{A. Fixing the baselines}

To fix the baselines, physical and legal approach can be attempted. As for physical approach, baselines are physically represented by coastlines so that stabilising baselines means preserving coastlines. Building sea defences, such as sea wall, groynes, and wave reduction structures, may be seen as alternatives to protect coastlines from being degraded by mainly natural occurrence in coastal area, such as erosion and abrasion. Similarly, reclamation can also be an option to build up vulnerable coastlines. Maldives has started projects to build up some big islands through reclamation so they have more safe refuges for its population. ${ }^{75}$

In the small islands or insulars context, physical intervention can also be an alternative. An LTE, for example, can be used as a basepoint connecting straight baselines if "lighthouses or similar installations which are permanently above sea level have been built on" the LTE. ${ }^{76}$ This indicates that physical intervention to LTE does influence its legal status to serve as a basepoint. The building of lighthouses and protecting them also means physically protecting the LTE which in turn protects/stabilises baselines. For other insulars features, physical intervention can also mean building structure such as sea defences to protect them from wave due to, for example, its critical role as a basepoint. An example for this is what Japan has done in protecting the Okinotorisima by building a 360-degree ring of sea wall around the small insular feature. ${ }^{77}$

The drawback of the physical approach described above is that it is certainly costly and may be environmentally unfriendly. The building of sea defences such as sea walls, wave reduction structures, etc has been proven expensive. Sea wall built by Japan for Okinotorisima costs no less than USD 200 millions in the 1980s. ${ }^{78}$ This is certainly not a preferable option for less

\footnotetext{
75 Morris, C. (2009). Maldives rises to climate challenge, BBC News online, 17 March 2009. Available at < http://news.bbc.co.uk/2/hi/7946072.stm> (last access on 30 August 2010)

76 LOSC Article 7 (4).

77 Prescott, JRV. and Schofield, C., (2005). The Maritime Political Boundaries of the World, Second Edition, Martinus Nijhoff Publishers, Leiden/Boston, pp. 84-85.

78 A 1991 estimate put the estimated cost of the project at $£ 135$ million. See, Brown, J., et al.
} 
developed States like Maldives, Tuvalu and other Small Islands Developing States (SIDS), which in fact, are the ones that suffer the sea level rise impact the most. With regard to the environmental consideration, physical intervention may disturb natural equilibrium and may cause serious "unintended consequences" in the long run. ${ }^{79}$ Ecologically, the building of coastal defence structures can also affect on a local and regional scale concerning the existence of species, which consequently may change the native assemblages of the surrounding areas..$^{80}$

Another issue regarding physical intervention such as reclamation is the legality of the new coastline resulting from reclamation to be used as baselines. If a coastal State can prove that the reclamation is part of harbour works that "form an integral part of the harbour system" then the reclamation "are regarded as forming part of the coast" ${ }^{81}$ which can be used as baselines. LOSC also asserts that artificial islands should not be regarded as permanent harbour works. The next question is "when does an island that was naturally formed, become artificial?" LOSC does not specifically define what constitutes artificial islands. Furthermore, there has been no clear guideline whether or not natural status can be reclaimed.

Having observed the above, it can be concluded that physical intervention approach to stabilise baselines is generally costly and tend to be environmentally and ecologically unfriendly. In addition, interventions such as reclamation may spark legal questions concerning the validity of reclaimed coastlines to be used as baselThe other effort in fixing baselines is the legal approach, which has also been introduced to retain maritime claims ${ }^{82}$ Two major alternatives are fixing the normal baselines or fixing the maritime limits. The LOSC states that normal baselines of a coastal State are the low-water line depicted on a nautical chart recognised by the coastal State. The key information in this article is that a recognised nautical chart is the legal document on which normal baselines of a coastal State are declared. On the other hand, there is no clause in the article detailing technical specification of the nautical chart. The LOSC does not either specifically mention, for example, the age of chart in question, or whether or not the chart needs to be registered to or recognised by an international body.

The above observation leads to a conclusion that it is up to the coastal State to use any chart in defining its normal baselines as long the chart is officially recognised by the coastal State. In order for a coastal State to have fixed baselines, it needs to have a fixed recognised chart showing the baselines. Consequently, the State does not need to revise and update the chart. In this case, the chart produced for the purpose of showing baselines must be different from that used for navigational purposes. For the latter, a nautical chart has to be regularly revised through surveys to show the most updated coastal environment and important objects, especially those hazardous to navigation.

(1991), Case Studies in Oceanography and Marine Affairs, Pergamon Press, Oxford, pp. 84-85.

79 Kenchington, R., (2009). Maintaining Coastal and Lagoonal Ecosystem and Productivity. In: Hiroshi Terashima (ed.), Proceedings of the International Symposium of Islands and Oceans, Ocean Policy Research Foundation, Tokyo, pp. 3-5

${ }_{80}$ Airoldi, L., et al. (2005). An ecological perspective on the deployment and design of low-crested and other hard coastal defence structures, Coastal Engineering Volume 52, pp. 1073-1087

${ }^{81}$ LOSC, Article 11.

82 See, in particular, Soons, A., (1990). The Effects of Sea Level Rise on Maritime Limits and Boundaries, Netherlands International Law Review, p. 207. 
This means that such coastal State needs to have different charts for navigational purposes and for baselines definition.

The potential issue with the use of specific and fixed charts showing baselines is that other States may not necessarily recognise the chart. This can be problematic if the two States need to delimit maritime boundaries between them. If one State fails to recognise other State's chart depicting normal baselines, the progress of the delimitation may be hampered. However, it is not unique that two States would agree on the use of particular chart for maritime delimitation even though the chart is reasonably 'old' and therefore does not depict the current coastline/baselines. A good example of this practice is the delimitation of maritime boundary between Indonesia and Singapore in the Singapore Strait, signed on 10 March $2009 .{ }^{83}$ Indonesia insisted that Singapore uses its 'old' normal baselines as depicted in the 'original map' of 1969 in the delimitation and Singapore for its side agreed to do so. ${ }^{84}$ To anticipate problems caused by disagreement on the use of fixed baselines depicted by a particular chart, coastal States can voluntarily declare their fixed normal baselines in the same manner as States usually declare straight or archipelagic baselines. By doing so, protest and disagreement from other States, usually neighbours, can be anticipated well in advance, before the baselines are used for maritime claims and delimitation.

The instability issue of normal baselines may also be partially overcome by the use of straight baselines. However, it is worth noting that straight baselines are not originally aimed at fixing baselines in response to global changes such as sea level rise. The use of straight baselines is in the context of deltas and unstable coasts..$^{85}$ This can consequently raise questions on the validity of straight baselines to be designated in response to the issue of sea level rise. In addition, while the most part of straight baselines is imaginary lines, they still require turning points, which should be points somewhere at the interface of land and water during low tide. Those turning points should not be imaginary and straight baselines cannot 'float' in the sea, unattached to any point on land. Accordingly, straight baselines still require the use of basepoints, the location of which depends on the choice low-water line, which is unstable in character. This implies that the use of straight baselines may fix baselines in particular location/situation but it does not fully resolve the instability issues. Other issues with straight baselines is that States tend to interpret Article 7 of the LOSC liberally in designating straight baselines since there are some uncertainties/ambiguities in the article causing it to be multi-interpreted. Accordingly, the straight baselines may be considered excessive by other States and, therefore, might be rejected.

83 MFA Indonesia, 2009, Press Release: The Signing of The Treaty Between The Republic of Indonesia and The Republic of Singapore Relating to The Delimitation of The Territorial Seas In The Western Part of The Strait of Singapore, Jakarta, 10 March. Available at <http://www.deplu.go.id/_layouts/mobile/ PortalDetail-PressReleaseLike.aspx?l=en\&ItemId=c148acb8-88c6-4e24-9dd3-352ec9cd90c2>(last access on 1 September 2010).

84 Press Release by the Government of the Republic of Indonesia during the working meeting of Commission one of DPR on the ratification of the agreement between the Republic of Indonesia and the Republic of Singapore regarding Maritime Boundary Delimitation between the two States in respect to western area of the Singapore Strait. Done in Jakarta, 24 Mei 2010. Available at <http://www.deplu.go.id/ Pages/SpeechTranscriptionDisplay.aspx?Name1=Pidato\&Name2=Menteri\&IDP=646\&l=id> (last access on 1 September 2010).

85 LOSC, Article 7 (2). 


\section{B. Fixing the limits}

Instead of stabilising normal baselines, fixing maritime limits may be seen as another alternative in dealing with changing environment due to climate change. This idea suggests that once maritime limits are set, they are permanent in term of location. Accordingly, it does not matter whether or not coastlines or baselines shift due to sea level rise, maritime limits stay where they are. Should this be adopted, States will not be disadvantaged if there is significant sea level rise that shifts baselines closer landward. However, States may not see this as a good option if for some reasons their baselines shift further seaward. This is possible if lands are growing, so that coastlines/baselines move further seaward. Ironically, this is scientifically proven for some Pacific States, which have long been believed to be sinking instead of growing. A thorough analysis using aerial photos and high-resolution satellite images for a period of 60 years to study changes in the land surface of 27 Pacific Islands was conducted by Paul Kench at the University of Auckland, New Zealand and Arthur Webb at the South Pacific Applied Geoscience Commission in Fiji. ${ }^{86}$ It has been identified by the scientists that the growing islands seem to be "largely due to coral debris, land reclamation and sediment." In this particular case, coastlines/baselines shift further seaward but maritime limits will stay where there are, which might not be preferable to States in the Pacific. However, considering that sea level rise is accelerating, it seems that in the future the possibility for island States in the Pacific sinking is bigger than that of growing. This might make the option of fixing maritime limits can gain support from climate change-vulnerable island States in the Pacific.

Fixed limits of maritime zones are in fact not a new idea. The outer limits of the continental shelf, when defined based on the recommendation provided by the Commission on the Limits of the Continental Shelf (CLCS), are final and binding. ${ }^{87}$ This suggests that any changes of baselines or geology and geomorphology of seabed will not cause any effect on the already-established outer limits of the continental shelf. However, the situation might be problematic, since it is possible that land territory for some reason no longer exists but the entitlement to seabed prevails. ${ }^{88}$ Another issue with these fixed maritime limits is that while it might be effective as a matter of domestic law it can be problematic in the international context. The limits, however, are unilateral claims and other States are not bound by such unilateral claims.

With regard to maritime boundary delimitation, there is no issue for agreed maritime boundaries since they do not change unless parties in question agree to do so. The 1969 Vienna Convention on the Law of Treaties states that boundary treaties are excluded from the rule that a party to a treaty may invoke "a fundamental change in circumstances" as a ground for terminating a treaty. ${ }^{89}$ In addition, the 1978 Vienna Convention on Succession of States in Respect of Treaties also provides that a change of States does not affect a boundary established by a treaty. ${ }^{90}$ While the change on baselines will not af-

${ }^{86}$ ABC News, Pacific islands growing, not sinking. Available at <http://www.abc.net.au/news/ stories/2010/06/03/2916873.htm> (last access on 28 August 2010).

87 LOSC, Article 76 (8).

88 Soons, A. (1990). The Effects of Sea Level Rise on Maritime Limits and Boundaries. See above note 81 .

89 Vienna Convention 1969, Article 62 (2) (a).

90 Vienna Convention 1978, Article 11 (a). 
fect the already agreed maritime boundaries, it can certainly affect the maritime boundaries being delimited. When baselines are given significant weight in maritime delimitation, location of maritime boundary lines varies in respect to the location of baselines of parties in question. In conclusion, instable baselines do not affect agreed maritime boundaries but can influence the process of maritime delimitation for new maritime boundaries.

\section{Summary/Conclusions}

One of the impacts of global warming is evident by, among other things, the increase of sea surface. In an extreme situation sea level rise may sink land fully or partially. This consequently causes the chance in coastline which in turns will change baselines. The change of baselines means the change of reference, from which the outer limits maritime zones are measured. For the baselines change, the outer limits of maritime zone of jurisdiction measured from them will eventually change. This confirms that climate change affect sovereignty and sovereign rights. In other words, climate change may cause the sinking of sovereignty and sovereign rights. Previous sections in this paper discuss the idea of mitigating the impacts of climate change to maritime jurisdiction and how to deal with it.

Fixing baselines is one of the proposed solutions by locating baselines in an imaginary location indicated by coordinates. The idea of imaginary islands in relation to baselines definition is by no means new. The normal baselines have always been represented by low-water lines which are almost always submerged. Accordingly, the effort to fix baselines by locating them in 'imaginary' location, which in turn fixes maritime limits in response to sea level rise, is not a new idea either. The idea proposed in this paper is certainly not the first one, as some similar thoughts have previously been published in regard to climate change and its impact to the law of the sea in general. However, this paper has highlighted some new developments which indicate the urgency of realising the aforementioned idea. Sea level rise or land subsidence are not only a reality, they are also accelerating.

While physical intervention to fix coastlines/baselines and maritime limits seems to be an alternative that works for particular circumstances, legal fixing is apparently more feasible. This can start from State practices where coastal States voluntarily declare or even deposit its normal baselines or maritime limits, analogues to the deposition of straight ${ }^{91}$ or archipelagic $^{92}$ baselines. Once declared on an official chart, normal baselines can stay at the same location until the particular chart is revised. In addition, normal baselines are the ones identified "on large-scale charts officially recognized by the coastal State" 93 and are not necessarily representative of the actual location of coastline. This supports the idea of fixing normal baselines by preserving charts assigned particularly for the purpose of depicting baselines.

Another more radical approach to have baselines fixed is to amend the LOSC. However, this approach seems to be rather unrealistic. Even though the

\footnotetext{
91 LOSC, Article 16 (2).

92 LOSC, Article 47 (9)

93 LOCS, Article 5.
} 
LOSC contains amendment procedures, it is unlikely that the procedure would be activated. UNCLOS IV does not seem to be a process that States Parties are keen to do in the near future. However, it has been evident that a supplementary agreement is not an impossible solution, such as Fish Stock Agreement of $1995 .{ }^{94}$ This previously-accepted solution can be used as a model in approaching the idea of fixing baselines and/or maritime limits.

Fixing baselines and/or maritime limits is basically preserving the existing rights of coastal States. For an archipelagic State like Indonesia, for example, the idea of fixing baselines and or maritime limits is preferable for its small islands, where basepoints and baselines are anchored, are physically prone to climate change. This idea is not to claim or secure maritime jurisdiction excessively but, instead, to maintain what a coastal State is already entitled to.

\section{Disclaimer:}

Part of this paper has been previously published in peer-reviewed publication or conferences. This current publication is modified and updated from the previously published works.

\section{Bibliography}

Walker, G. and King, D. 2008. The Hot Topic: How to Tackle Global Warming and Still Keep the Lights On, London.

Tarigan, M. S. 2007. Perubahan Garis Pantai Di Wilayah Pesisir Perairan Cisadane, Provinsi Banten, Makara, Sains, Vol. 11, No. 1, April 2007: 49-55

Leiserowitz, A. A. 2005. American Risk Perceptions: Is Climate Change Dangerous?, Risk Analysis, Vol. 25, No. 6.

Duzheng, Y. Yundi, J. and Wenjie, D. 2003. The northward shift of climatic belts in China during the last 50 years and the corresponding seasonal responses, Advances in Atmospheric Sciences, Volume 20, Number 6, pp. 959-967.

Walker and King, 2008: 778-780 in Schofield, C. and Arsana, I M. A., Imaginary Islands? Options to Preserve Maritime Jurisdictional Entitlements and Provide Stable Maritime Limits in the Face of Coastal Instability, Ablos Conference, Monaco, 25-27 October 2010. See above note 3 and 4

Sutanta, H., Rajabifard, A. and Bishop, I. D. 2009. "An Integrated Approach for Disaster Risk Reduction Using Spatial Planning and SDI Platform", pp.341-351 in Ostendorf B., Baldock, P., Bruce, D., Burdett, M. and P. Corcoran (eds). Proceedings of the Surveying \& Spatial Sciences Institute Biennial International Conference, Adelaide 2009, Surveying \& Spatial Sciences Institute.

United Nations Conventions on the Law of the Sea (LOSC), opened for signature 10 December 1982, in force 16 November 1994, 1833 UNTS 3.

$94 \quad$ The United Nations Agreement for the Implementation of the Provisions of the United Nations Convention on the Law of the Sea of 10 December 1982 relating to the Conservation and Management of Straddling Fish Stocks and Highly Migratory Fish Stocks (in force as from 11 December 2001). Available at <http://www.un.org/Depts/los/convention_agreements/convention_overview_fish_stocks.htm> (last access on 3 September 2010). 
Prescott, J.R.V. and Schofield, C.H. (2005) The Maritime Political Boundaries of the World (Leiden/Boston: Martinus Nijhoff Publishers), at pp.239-241.

Beckman, R., and Schofield, C. (2009) "Moving Beyond Disputes Over Island Sovereignty: ICJ Decision Sets Stage for Maritime Boundary Delimitation in the Singapore Strait", Ocean Development and International Law, Vol. 40:1: 1-35, at p. 5.

Sobey, R. J., (2005). Extreme low and high water levels, Coastal Engineering, Vol. 52, p. 65.

Carleton, C.M. and Schofield, C.H. (2001) Developments in the Technical Determination of Maritime Space: Charts, Datums, Baselines, Maritime Zones and Limits, Maritime Briefing, 3, 3, Durham: International Boundaries Research Unit, at p.62.

Pruett, L. 2004. Area Calculations of the Claims and Potential Claims to Offshore Jurisdictional Zones and High Seas, unpublished data derived from the August 2003 Edition of the Global Maritime Boundaries Database, General Dynamics, Herndon, VA, USA, in Prescott, V. and Schofield, C. 2005. The Maritime Political Boundaries of the World, 2nd edition, Martinus Nijhoff Publishers, p. 9, 27

Prescott, JRV. and Schofield, C., (2005). The Maritime Political Boundaries of the World, Second Edition, Martinus Nijhoff Publishers, Leiden/Boston, 218

Reed, M. Shore and sea boundaries: the development of international maritime boundary principles through United States practice, (Washington D.C.: US Department of Commerce, 2000), at 185; Prescott and Schofield, Maritime Political boundaries of the World, supra note 22, at 100-101.

Hirst, W. and Robertson, D., "Geographic Information Systems, Charts and UNCLOS - Can They Live Together?", Maritime Studies, 136 (May-June 2004), at 1-6.

Schofield, C.H. 'Shifting Limits?: Sea Level Rise and Options to Secure Maritime Jurisdictional Claims'(2009) 4 Carbon and Climate Law Review, pp.405-16, at pp.409-410.

Carleton, C.M. and Schofield, C.H. (2001) Developments in the Technical Determination of Maritime Space: Charts, Datums, Baselines, Maritime Zones and Limits, Maritime Briefing, 3, 3, Durham: International Boundaries Research Unit, at p.62.

Patel, S. S. (2006) A Sinking Feeling, Nature Vol. 44, 6 April 2006, p. 734.

Montevideo Convention on the Rights and Duties of States, opened for signature 26 December 1933, 165 LNTS 19 (entered into force 26 December 1934), Article 1.

Prescott, JRV. and Schofield, C., (2005). The Maritime Political Boundaries of the World, Second Edition, Martinus Nijhoff Publishers, Leiden/Boston, pp. 84-85.

Brown, J., et al. (1991), Case Studies in Oceanography and Marine Affairs, Pergamon Press, Oxford, pp. 84-85.

\section{Articles}

Airoldi, L., et al. (2005). An Ecological Perspective on the Deployment and Design of Low-Crested and Other Hard Coastal Defence Structures, Coastal Engineering Volume 52, 1073- 1087.

Soons, A., (1990). The Effects of Sea Level Rise on Maritime Limits and Boundaries, Netherlands International Law Review 207. 
Dupont, A. (2008) The Strategic Implications of Climate Change, Survival, Volume $50: 3$, p.36.

\section{Conference Paper}

Schofield, C. and Arsana, I M. A., Imaginary Islands? Options to Preserve Maritime Jurisdictional Entitlements and Provide Stable Maritime Limits in the Face of Coastal Instability, Ablos Conference, Monaco, 25-27 October 2010.

Kenchington, R., (2009). Maintaining Coastal and Lagoonal Ecosystem and Productivity. In: Hiroshi Terashima (ed.), Proceedings of the International Symposium of Islands and Oceans, Ocean Policy Research Foundation, Tokyo, pp. 3-5

\section{Internet}

ABC News, Pacific islands growing, not sinking. Available at $<$ http://www. abc.net.au/news/stories/2010/06/03/2916873.htm> (last access on 28 August 2010).

ABS News, 2007. Indonesia May Lose 2,000 Islands to Warming: Minister Says Climate Change Could Lead To Rising Sea Levels, Accessed from < http://www.nbcnews.com/id/16867998/ns/world_news-world_environment/\#.UhiUEj8vnDY>, on 15 August 2013.

Reuters 2007. Climate change may wipe some Indonesian islands off map, Accessed from <http://www.reuters.com/article/2007/12/03/environment-climate-indonesia-islands-dc-idUSJAK15507820071204> on 10 March 2011

The Times Online 2009. EU's new figurehead believes climate change is a myth, The Times Online 2 January 2009. Diakses dari <http://www. timesonline.co.uk/tol/news/world/europe/article5430362.ece> tanggal 3 Maret 2011.

Daily Mail 2007. Greenhouse effect is a myth, say scientists. Diakses dari <http://www.dailymail.co.uk/sciencetech/article-440049/Greenhouse-effect-myth-say-scientists.html> tanggal 15 Maret 2011

Presiden RI 2011. Presiden Hadiri Pencanangan Gerakan Nasional Menghadapi Anomali Iklim. Diakses dari < http://www.presidenri.go.id/index. php/fokus/2011/01/14/6347.html> tanggal 5 Maret 2011.

IPCC 2007. IPCC's Fourth Assessment Report (AR4). Diakses dari <http:// www.ipcc.ch/\#> tanggal 12 Maret 2011.

CSIRO 2009. The science of climate change, CSIRO. Diakses dari <http://www. csiro.au/files/files/poqu.pdf> tanggal 12 March 2011.

The IPCC's Fourth Assessment Report (AR4), available on the internet at, <http://www.ipcc.ch/\#> (last accessed 21 November 2009).

Department of Climate Change 2009. Climate Change Risks to Australia's Coast: A First Pass National Assessment available at <http://www.climatechange.gov.au/en/publications/coastline/climate-change-risksto-australias-coasts.aspx>.

Antara 2008 2000. Pulau Akan Tenggelam pada 2030. Diakses dari <http:// www.antaranews.com/view/?i=1204115346\&c=WBM\&s=> tanggal 10 Maret 2011

Climate Kelpie 2010. Climate variability and climate change - what's the difference? Diakses dari <http://www.climatekelpie.com.au/understand-cli- 
Leahy, F.J., Murphy, B. A., Collier, P. A., and Mitchell, D. J., (2001). Uncertainty Issues in the Geodetic Delimitation of Maritime Boundaries, Proceeding of the 2001 ABLOS Conference. Available at <http:// www.gmat.unsw. edu.au/ablos/ABLOS01Folder/LEAHY.PDF> (last accessed 29 August 2010).

Wade, M. (2009) Rising sea level settles border dispute, The Sydney Morning Herald. Available at <http://www.smh.com.au/environment/climatechange/rising-sea-level-settles-border-dispute-20100324-qwum. html> (last access on 28 August 2010). 